\title{
KONTROVERZNÍ VÝSTAVY A JEJICH REFLEXE U MUZEJNÍHO NÁVŠTĚVNÍKA

\author{
RENÁTA ŽÁKOVÁ
}

\begin{abstract}
ABSTRAKT/ABSTRACT:
Příspěvek prezentuje část diplomové práce s názvem Kontroverzní témata v muzejních výstavách. Zabývá se náměty a obsahem kontroverzních výstav navštívených muzejním publikem. Sleduje důsledky vzniku kontroverze za účelem zvýšení efektivity práce s interpretačně obtížnými problematikami. Konstruuje tematické dělení výstav, u něhož lze kontroverznost výstav dále posuzovat dle pěti nejčastějších oblastí vzniku rozporu: identity, autenticity, estetiky, etiky a práva.
\end{abstract}

\section{Controversial exhibitions and their reflection by a museum visitor}

The paper presents a part of the diploma thesis titled Controversial themes in museum exhibitions. It deals with the topics and the content of controversial exhibitions visited by the museum audience. It monitors the roots of controversy in order to increase the efficiency of work with interpretatively difficult issues. It designs the thematic division of exhibitions, where the controversy in exhibitions can be further assessed according to the five most common areas of controversy: identity, authenticity, aesthetics, ethics and law.

\section{KLÍČOVÁ SLOVA/KEYWORDS:}

muzejní výstavnictví - kontroverze výstava - muzejní návštěvník reflexe museum exhibition - controversy exhibition - museum visitor reflection

\section{1. Úvod}

Kontroverze je slovo, s nímž se v současné době setkáváme čím dál tím častěji. Objevuje se ve všech typech veřejných médií. At̃ už jej spatříme $\mathrm{v}$ tisku, uslyšíme na konferenci nebo zhlédneme $\mathrm{v}$ televizi, jeho obsah má vždy obdobnou významovou náplň. Jelikož i muzea jsou chápána jako média, s kontroverzí přicházejí taktéž do styku. Disponují vlastními interpretačními nástroji, a tudíž mají na rozporuplné situace výstavní činnosti přímý vliv. Opakované diskuse a reflexe tématu kontroverze ve společnosti podnítily tendence se jím hlouběji zabývat.

Výše uvedené úvahy daly vznik magisterské diplomové práci s názvem Kontroverzní témata v muzejních výstavách. Úkolem následujícího příspěvku, vyplývajícího z části diplomové práce, je prezentovat klíčovou charakteristiku této problematiky s důrazem na vybranou kapitolu tematického zaměření kontroverzních výstav. Článek se nejprve zabývá vysvětlením samotného pojmu kontroverze. Zasazuje jeho význam do prostředí muzejně výstavní činnosti a objasňuje epicentra jeho vzniku. Uvádí dále názorné př́́klady propojení jednotlivých důsledků kontroverze, čím ukazuje na nezbytnost chápání pojmu v souvislostech. Stěžejní část je zaměřena na dotazníkové šetření návštěvníků muzeí a galerií, které zkoumá jejich vztah $\mathrm{k}$ výstavám $s$ rozporuplnou tematikou. Soustředí se především na navštívené výstavy v odpovědích respondentů. Hledá ekvivalenty jejich interpreta- ce v odborné literatuře, porovnává je a vyvozuje závěry.

\section{Role kontroverze ve výstavě}

Kontroverze je nejčastěji vnímána jako názorový střet či rozpor. Pro identifikaci vzniku kontroverze $\mathrm{v}$ prostředí muzea lze vyčlenit tř̀ základní aspekty. První zahrnuje tzv. interpersonální rovinu, kontroverze je kolektivní záležitostí, rozpor se odehrává mezi osobami. Často jde o skupiny lidí s proti sobě jdoucími názory. Ve výstavě závisí problematika kontroverze zejména na prezentovaném tématu. To může být kontroverzní svou vlastní povahou. Muzeum tak přijímá $\mathrm{k}$ interpretaci společensky citlivý materiál a v jeho zájmu spočívá, brát tuto skutečnost na vědomí. Obecně hovoříme o rozporuplnosti, která vyplynula ze situace nezávislé na muzejní práci, tedy ještě před přijetím námětu institucí muzea. V dalším př́ípadě stojí za kontroverzí realizační tým výstavy. Nadsázka $\mathrm{v}$ interpretaci působící skrze výrazovost sdělovacích prostředků, tvoří přičinu mnohých zkreslení původního záměru. Např. neuváženou kreativitou dochází k situaci, jíž vykládáme jako kontroverzi započatou v muzeu. Poslední př́íklad interpersonální roviny kontroverze vychází z odlišného vnímání tématu většinovou či menšinovou veřejností. Prvky kontroverze jsou specifické, tendence diskutovat a vyjádřit se $\mathrm{k}$ tématu směřují od sociálních skupin směrem $\mathrm{k}$ muzeu. Iniciátory jsou přesvědčení vlastní kultury a potřeba tyto zásady prosadit. Kontroverze vzniká nezávisle na tématu i na realizaci, pro podnět 
rozporu nejsou primárně důležité okolnosti ale podnět sám o sobě. Výstava působí jako př́ležitost.

Druhý aspekt má intrapersonální charakter. Kontroverze je individuální záležitostí. Je spojena s psychickými stavy a procesy konkrétní osoby. Vymezení postoje vůči tématu výstavy bývá ovlivněno konkrétními prožitky osobnosti. Rozpor má vnitřní rozměr. Projev vnímání kontroverze však může být velmi silný, tudíž jej nelze v porovnání $\mathrm{s}$ většinovými ohlasy považovat za méně důležitý.

S třetím aspektem se setkáváme při tzv. aktualizaci dějin. Jedná se o společensky citlivou událost $\mathrm{z}$ minulosti, okolo níž se $\mathrm{v}$ současnosti znovu otevřely diskuze. Role kontroverze je dána „kolektivní pamětí“. ${ }^{1}$

Na základě studované literatury a kritického myšlení, byl pojem kontroverze uvažován $\mathrm{v}$ pěti klíčových oblastech svého vzniku, kterými jsou identita, autenticita, estetika, etika a právo. Při řešení kontroverzních situací ve výstavách se vyskytují propojeně s výraznějším zatížením na jednu $\mathrm{z}$ nich. Identita odkazuje $\mathrm{k}$ problematice sebeurčení, je spjata s kulturou a jejími projevy. V muzejní prezentaci se s ní setkáváme např. v tématech osobních příběhů, sociálních útvarů společnosti nebo náboženství. Kontroverzi v oblasti autenticity nalezneme $v$ souvislosti s produkty kultury a jednotlivců. Dotýká se otázek autorství, výpovědní hodnoty vystavených exponátů a také kvality interpretace. Estetika spolu $s$ etikou pak na tyto podněty navazují. V př́padě těchto dvou pojmů se jedná především o vizuál a sílu výrazových prvků výstav. Je užitečné mít na paměti, že $v$ některých př́ípadech muzejních instalací může kreativita spíše škodit. Zejména

1 MASLOWSKI, Nicolas a Jiří ŠUBRT. Kolektivní pamět: $k$ teoretickým otázkám. Praha: Karolinum, 2015, s. 47. z etických důvodů, např. prezentujeme-li autority. Oblast práva je jedinou, vymezující kontroverzi pevné hranice. Usměrňuje tedy proces rozhodování ve volbě námětů výstav včetně jejich zpracování. ${ }^{2}$

\section{Výzkumná část - dotazníkové šetření}

Jeden z dílčích požadavků při práci s kontroverzí ve výstavách spočíval v implementaci teoretických poznatků problematiky do muzejní praxe. Další postup tak vyžadoval provedení analýz, u nichž by bylo možné vyvodit relevantní závěry a informace dále konfrontovat $s$ již existujícími.

S pomocí studia odborné literatury a vlastního úsudku byly stanoveny hypotézy, u nichž se předpokládalo jejich následné potvrzení či vyvrácení. Pro získání funkčních odpovědí na otázky kontroverze ve výstavách bylo proto realizováno dotazníkové šetření zaměřené na návštěvníky muzeí a galerií. Sběr responsí probíhal od 6. listopadu 2017 do 2. května 2018. Cílem bylo zjistit, jaké postoje ke kontroverzi zastávají návštěvníci muzeí, a které faktory mají na její vznik vliv.

\subsection{Model dotazníku}

Dotazník obsahující celkem 15 otázek byl $\mathrm{k}$ dispozici online na internetu ${ }^{3} \mathrm{a} v$ tištěné podobě. Otázky byly koncipovány formou otevřených i uzavřených odpovědí. Obsah dotazníku bychom mohli rozdělit na 4 pomyslné tematické celky. První z nich kladl otázku směrem k chápání základního pojmu „kontroverze“. Druhý se tázal návštěvníka na zkušenosti s kontro-

\footnotetext{
2 ŽÁKOVÁ, Renáta. Výstavní menu aneb jak podávat kontroverzi. In TIŠLIAR, Pavol (ed.). Studia Museologica Slovaca, 2018, vol. 2. Bratislava: Muzeológia a kultúrne dedičstvo, 2018, s. 51-55. 3 Dotazník je dostupný zde: Výstava plná rozporu - dotazníkové šetření vztahu návštěvníků muzeí a galerií ke kontroverzním výstavám [online]. [cit. 2018-11-15]. Dostupný z www: <https://www. survio.com/survey/d/W4X9N0T9U1X1B5E8N>.
}

verzními výstavami. Ptal se, kolikrát za posledních pět let navštívil takovou výstavu, jaká kontroverzní výstava $v$ něm zanechala nejsilnější zážitek, zda se jeho názor s názorem výstavy shodoval, jak moc ho podnítila $\mathrm{k}$ dalšímu zájmu, včetně toho, zdalipak se tématu dále věnoval. Třetí část zjištovala, zažil-li dotázaný výstavu, která jej doslova šokovala a pokud ano, tak čím. Ve čtvrtém celku mu dal možnost uvést, zda rád navštěvuje výstavy, které jej vedou k zamyšlení, jaká témata by uvítal nebo na co by nesnesl pohled. Poslední tři otázky se týkaly obecných identifikačních údajů o respondentovi. Dotazník požadoval, aby uvedl, kolik je mu let, své pohlaví a nejvyšší dosažené vzdělání.

\subsection{Interpretace výsledků šetření}

Dotazníkového šetření se zúčastnilo 210 návštěvníků muzeí a galerií. Vyšlo najevo, že ženy mají mnohem větší ambice vyjadřovat se $\mathrm{k}$ tématu rozporu než muži. Zjištění dokládala dvoutřetinová účast žen z celku všech navrácených vyplněných dotazníků. $\mathrm{Z}$ hlediska věkového složení vítali kontroverzi nejvíce mladší lidé do 45 let. Roli v zájmu o myšlenkově hlubší témata hrála také úroveň vzdělání respondentů. Uvedená skutečnost byla vysvětlena na základě studia tématu kulturního kapitálu obsaženého v odborné literatuře. Výsledky dále ukázaly, že význam pojmu kontroverze je nejčastěji spojován se střetem zájmů. Kromě tohoto tvrzení vznikly na základě analýzy tř́ídění responsí dle jejich významové náplně další relevantní kategorie. Identifikovaly pojem kontroverze z pozitivního a negativního pohledu, vykládaly jej jako provokaci, polemiku a inovaci. Návštěvníci se v největší míře účastnili výstav reflektujících současné dění. Uvedený fakt se stal zároveň motivem pro hlavní tezi tohoto článku, který se jím podrobněji zabývá, viz níže. Stěžejní důraz ve vzniku rozporu 
přikládali konkrétním vystaveným předmětům. To vyvrátilo hypotézu očekávající platnost tvrzení v souvislosti s celkovou atmosférou provedení výstavy. Stejně tak došlo k vyvrácení předpokladu, že zájem o obtížná témata končí návštěvou výstavy. Hypotézu popřela více jak 50 \% angažovanost projevovanou zejména pasivním vyhledáváním navazujících informací o navštívené problematice. Respondenty nejvíce šokoval obsah výstav, které navštívili. Uvedený poznatek zde znovu potvrdil skutečnost o soustředění pozornosti při prohlídce prezentačních prostor na instalované exponáty. Valná většina respondentů má zájem o výstavy, které vedou člověka k zamyšlení a nejvíce by uvítala reflexi aktuálního dění. Témata, která naopak vidět nechtějí, se týkají nejčastěji násilí a smrti.

Souhrnné výsledky dotazníkového šetření orientovaného na návštěvníky potvrdily response ankety směřované na muzejní instituce, jejímž účelem bylo získat zpětnou vazbu. Drobné rozdíly vyvstávaly z upozornění institucionálních záležitostí, jako je problém medializace výstav a ekonomická stránka.

\subsection{Tematický rozbor výstav na- vštívených respondenty}

Hlavním předmětem tohoto příspěvku je interpretovat výsledky spojené s popularitou kontroverzních námětů a obsahů výstav u muzejních návštěvníků. Zaměřme se nyní na otázku č. 3, obsaženou ve druhém tematickém bloku dotazníku a vysvětleme potvrzení stanovené hypotézy, která říká, že za kontroverzní bývají nejčastěji považovány výstavy reflektující současnost.

V jednotlivých odpovědích na tuto otázku, zabývající se navštívenými kontroverzními výstavami, se vyskytlo obsahově rozmanité množství př́ikladů. Tyto příklady bylo možno strukturovat dle příslušných entit tvořených souhrnnými pojmenováními. Vznikly tak 4 kategorie udávající směr k nejčastěji řešeným otázkám dnešní doby nebo k otázkám dějin, které i nadále budí pozornost. Rozdělení v první kategorii zahrnovalo témata výstav odkazující k minulosti, druhá kategorie pojednávala o problémech současné společnosti, třetí se zabývala identitou a čtvrtá autorskou a uměleckou tvorbou. Samostatně pak vystupovaly názory respondentů, jež nešly pro svou specifičnost pevně zařadit do žádné z uvedených kategorií.

\subsubsection{Témata odkazující k minu- losti - 18 responsí}

Více jak polovina těchto témat, byla ztvárněna $\mathrm{v}$ rámci projevu výtvarného umění. $\mathrm{V}$ této kategorii se sešlo celkem 18 reakcí. Její dílčí členění obsahuje témata týkající se 1) uměleckých slohů a stylů (6 responsí), 2) životního stylu (2 response), 3) společenských subkultur (2 response), 4) otázek interpretace obecné historie a politických dějin (8 responsí). S uvážením interdisciplinárního přístupu, je vedle stanovených kategorií vždy uvedeno v závorce typologické zařazení dle klasifikace výstav D. Šindeláře. ${ }^{4}$

Umělecké slohy a styly („výstavy hodnotící a prehodnocující") $)^{5}$ 6 responsí

Z dotazníků jsou patrné 2 záznamy o výstavě s názvem Ozvěny Secese ${ }^{6}$ konané na jaře roku 2018 v Prostějově a v Olomouci. Výstava byla návštěvníky vnímána jako kontroverzní právě z důvodu své interpretace. V situacích instalací historických témat hrozí informační

\footnotetext{
4 Ukázka typologie a klasifikace výstav podle D. Šindeláře, Umění ve vědomí společnosti, s. 66. In ŠTĚPÁNEK, Pavel. Obrysy muzeologie. Olomouc: Univerzita Palackého v Olomouci, 2002, s. 71. 5 Tamtéž.

6 Ozvěny Secese. In Galerie města Olomouce [online]. [cit. 2018-06-09]. Dostupný z www: <http://www.galerie-mesta-olomouce.cz/ aktualita/cz/66>.
}

zkreslení, a to především $\mathrm{z}$ důvodů nedostatečné možnosti je důkladně pochopit. Absence prožitku činí výklad obtížnějším.

Mezi dalšími se v dotaznících vyskytovala čistě umělecká témata, např. autoři 20. století v Ostravské galerii, ČS Koncept 70. let ve Fait Gallery v Brně, ${ }^{7}$ výstava Andy Warhol v opavském Domě umění Oko. ${ }^{8}$

K uzavření prvního tématu navštívených kontroverzních výstav lze dodat, že získané názory respondentů odpovídají většinovému přístupu k modernímu umění, ale i k umění jako takovému. Tudíž potvrzují myšlenku rozporu ve výkladu formou uměleckého díla, do něhož se promítá silný vliv osobnosti samotného autora.

\section{Životní styl („výstavy hodnotící a prehodnocující“) $)^{9}-2$ response}

V odpovědích se objevuje výstava Moravské galerie v Brně, Paneland, která trvala od listopadu 2017 do března 2018. Rozporuplná je již svým tématem, nebot pojednává o výstavbě panelových sídlišt v 70. a 80. letech 20. století jako o experimentu, a to jak v architektonické, tak i v sociologické a psychologické rovině. Vnější systém, včetně vnitřní struktury budov, byl úzce provázán s idejemi socialistického Československa. Model vzájemně si prospívající komunity panelových domů, jež poskytovaly zázemí převážně mladým rodinám a nabízely veškeré služby od gastronomických zařízení až po mateřskou školku, své poslání nenaplnil. Nedostatek finančních prostředků mladých obyvatel nebo pocity

\footnotetext{
7 ČS koncept 70. let. In Fait Gallery [online]. [cit. 2018-06-09]. Dostupný z www: <https://www. faitgallery.com/soucasne-a-planovane/events/244. html $>$.

8 Andy Warhol - 15 minut slávy. In Opavská kulturní organizace [online]. [cit. 2018-06-09]. Dostupný z www: < http://dumumeniopava. $\mathrm{cz} /$ ? $\mathrm{s}=$ Andy + Warhol $>$.

9 Viz poznámka 4.
} 
ztráty soukromí se staly předmětem řady diskusí. ${ }^{10}$ Problematika je vzhledem $\mathrm{k}$ době svého vzniku stále živá.

Dotázaní vzpomínali i tematicky blízce zaměřenou výstavu Brno moravský Manchester, pojednávající o rozmachu textilního průmyslu $\mathrm{v}$ Brně a $\mathrm{s}$ tím spojené proměny městského reliéfu i dopadu této situace na život obyvatel. Právě kontrast mezi prosperujícím světem módy a odívání a chudobou rodin osob zaměstnaných $\mathrm{v}$ továrnách vytváří důvody ke kontroverzi.

Jmenované výstavy nasvědčují, že projevy životního stylu jsou častým předmětem kritiky a přehodnocování. Podléhají vývoji a dobovým trendům $\mathrm{s}$ orientací $\mathrm{k}$ naplnění potřeb společnosti, opírajícím se o relevantní morální zásady.

Výstavy o společenských subkulturách („výstavy skupinové") ${ }^{11}$ 2 response

Kontroverze $\mathrm{v}$ této problematice je s ohledem na názory respondentů nejvíce viditelná na př́́kladu výstavního projektu Kmeny 90, probíhajícího od května do října 2017. Cílem projektu bylo prezentovat charakteristické rysy období 90 . let 20. století, které se projevovaly skrze tzv. alternativní kultury, což byly skupiny osob vystupující z většinové společnosti formou sdílení společných zájmů nebo typické vizáže. Na dotázané však tentokrát nepůsobil rozporuplně námět, ale jeho obsah a metody zpracování instalace výstavních objektů. Tomu nasvědčuje skutečnost různorodosti pohledů na reflektované období. 90. léta jsou zakořeněna i ve vzpomínkách poměrně mladé části populace, jejíž zkušenosti se mo-

10 Paneland. Největší československý experiment. In Moravská galerie [online]. [cit. 2018-06-10].

Dostupný z www: < http://www.moravska-galerie. cz/moravska-galerie/vystavy-a-program/aktualni-vystavy/2017/paneland.aspx >.

11 Viz poznámka 4 hou lišit. Vladimir 518, jako autor výstavy, však jednotlivým odlišnostem nepřikládá tak velký důraz, ale vyzdvihuje dekádu 90. let spíše jako celek s klíčovými projevy vnesenými do společenského povědomí, což ji činí rozpoznatelnou. I přesto u některých lidí převládá dosti konkrétní obraz vlastního prožitku vymykající se tomu nainstalovanému ve výstavě. ${ }^{12}$

Výstavy o obecné historii a politických dějinách („výstavy krajové, politické, vzpomínkové a jubilej$\left.n i^{\prime \prime}\right)^{13}-8$ responsí

Z 18 respondentů, reagujících na výstavy prezentující minulost, celkem 8 vnímalo kontroverzi v tématech politických režimů, válečných a dalších událostí, u nichž došlo $\mathrm{k}$ demografickým změnám. Ze získaných odpovědí můžeme jako prríklad uvést tvorbu Jozefa Jankoviče, vystavovanou v Muzeu umění v Olomouci v období od října 2017 do března 2018. Skulptury a plastiky znázorňující torza lidských těl nebo různé tělesné deformace, odkazují přenesením svého významu do abstraktnější roviny, k omezením komunistickým režimem. $\mathrm{V}$ př́ípadě Jankovičova uměleckého podání je problematika vztažena k zásahům do autorské tvorby. Výstava je vnímána jako kontroverzní, jelikož v sobě zahrnuje všech pět atributů vzniku kontroverze a totiž, dotýká se oblastí identity, autenticity, etiky, estetiky i práva, viz zmínka v úvodním odstavci. Identitu zde ztělesňuje sám autor, který vkládá vlastní zodpovědnost taktéž za autentické provedení. Protože jsou výstupem umělecké objekty, je téma citlivé esteticky a se zřetelem ke zvolenému způsobu tvorby také eticky. Těžiště samotné problematiky leží v otázce práva. S obdobným

\footnotetext{
12 Kmeny 90. In Moravská galerie [online]. [cit. 2018-06-06]. Dostupný z www: <http://www. moravska-galerie.cz/moravska-galerie/vystavya-program/aktualni-vystavy/2017/kmeny-90. aspx $>$.

13 Viz poznámka 4.
}

námětem se dotázaní setkali ve výstavě Život a dílo od Magdaleny Abakanowicz pořádané $\mathrm{v}$ roce 2011 taktéž v MUO. Autorka tvorbou bezhlavých soch demonstruje pocity člověka $\mathrm{v}$ minulém století. ${ }^{14}$

K období komunismu se váže také Rekonstrukce jako tragédie a fraška. Tímto názvem pojmenované sousoší, karikaturně znázorňuje smrt migrujícího Hartmuta Tautze, občana východního Německa, strážnickým psem. Základním motivem jsou přihlížející postavy strážníků. Sousoší bylo vytvořeno uměleckou skupinou Pode Bal. Poukazuje na nevyřešené zločiny komunistické éry. ${ }^{15}$

Návštěvníci uváděli i další kontroverzně vnímané příklady, mezi nimiž můžeme jmenovat Leporelo Dějin udatného národa Českého v knihovně Jiř́iho Mahena v Brně, expozici věnovanou památce obětí Černobylu v černobylské oblasti. Dále připisovali rozporuplnost obecně veškerým historickým interpretacím.

Z uvedených reakcí vyplývá skutečnost, že návštěvníci považují $\mathrm{v}$ oblasti politiky a dějin minulosti za nejvíce kontroverzní témata, spojená s obdobím 2. poloviny 20. století. Z pohledu na časovou přímku celé historie lidstva se jedná téměř o její prozatímní konec, což znamená vysokou aktuálnost jeho dění. Susan Pearce upozorňuje na tři faktory vlivu v pochopení určitého poznatku, a totiž na objekt, skupinovou a individuální realitu. Objektem je v našem př́ípadě dějinná událost včetně svých hmotných

\footnotetext{
14 Magdalena Abakanowicz. Život a dílo. In Muzeum umění Olomouc [online]. [cit. 2018-0606]. Dostupný z www: <http://www.muo.cz/ vystavy-2011/magdalena-abakanowicz-zivota-dilo--340/>

15 V muzeu Kampa je k vidění kontroverzní sousoší umělecké skupiny Pode Bal. In Lidovky. $c z$ [online]. [cit. 2018-06-12]. Dostupný z www: $<$ https://www.lidovky.cz/v-museu-kampa-jek-videni-kontroverzni-sousosi-umelecke-skupinypode-bal-1qm-/kultura.aspx?c=A150720_110338 ln_kultura_hep $>$.
} 
dokladů. Její interpretace se děje prostřednictvím společnosti i jednotlivce. Tyto tři faktory však nemusí mít stejný obsah. Událost jako taková se může naprosto vymykat prožitku jednotlivce a stejně tak většinové zkušenosti. Také jednotlivec může být $\mathrm{v}$ rozporu s většinou. Vrátíme-li se k poznámce o živosti problému, což svědčí o pravděpodobné informační obsáhlosti, je přirozené, že intenzita prožitku bude díky tomu mnohem vyšší, než u vnímání starších dějin. Do rozporu se $\mathrm{v}$ takovém případě dostávají účastníci, kteří disponují bohatou zásobou zosobněných argumentů. ${ }^{16}$

\subsubsection{Výstavy o současných pro- blémech - 68 responsí}

68 dotázaných považovalo za kontroverzní výstavy odkazující k současným společenským problémům. Jejich vyjádření bychom mohli zahrnout pod tři stěžejní pojmenování. Jsou jimi výstavy o př́stupech $k$ životu, výstavy o otázkách vnímání intimity a výstavy o protizákonných jednáních.

\section{Výstavy o přístupech $\mathbf{k}$ životu} ("hodnotící a prehodnocujíci“) ${ }^{17}$ 48 responsí

Kategorii zastoupenou 48 respondenty charakterizují témata spojená s uvažováním dnešního člověka o situacích jako je nakládání s informacemi, smrt, etika zacházení se zvířaty, morálka mládeže či zaběhnuté vzorce společenského smýšlení. 4 reakce z uvedených 48 se vztahují ke stejné výstavě s názvem Nervous Trees, jejímž autorem je český, mezinárodně uznávaný umělec Krištof Kintera. Pro jeho tvorbu jsou typické rozměrné instalace obsahující materiály a produkty současné doby. Elektronikou, kabely a dalšími výrobky

16 TABORSKY, Edwina. The discursive Objects. In PEARCE, Susan. Objects of knowledge. London: The Atlone Press, 1990, s. 50-77

17 Viz poznámka 4 z polymerů vysvětluje konfrontaci s člověkem. Prostřednictvím těchto předmětů znázorňuje metaforu k lidské nervové soustavě a hledá souvislosti mezi ní a jejími produkty, ${ }^{18}$ které lze pojmenovat artefakty neboli předměty vytvořené člověkem. Z důvodu masového užívání technologií v dnešním světě a s tím spojená řada vnitřních tedy osobních a vnějších společenských problémı̊, nelze pochybovat, že je právě toto téma vnímáno jako kontroverzní. Objevuje se zde také podnět k projektu Big Light, který se zamýšlí nad problematikou důvěryhodnosti a uchovávání informací. Big Light je svým obsahem velmi blízký předchozí výstavě Nervous Trees. Obě výstavy v širším významovém pojetí zahrnují všechna klíčová témata, viz výčet situací na začátku tohoto odstavce, jež jsou chápána jako častý důsledek „uživatelského" způsobu života.

Návštěvníci v této oblasti jmenovali nejčastěji interpretace zaměřené na téma, jehož znění je shodné s názvem konkrétní výstavy Smrt. Vzhledem ke globálnímu rozměru daného tématu, bylo učiněno rozhodnutí, vyvinout na jeho reflexi $\mathrm{v}$ rámci této práce větší důraz. Národním muzeem netradičně uchopená problematika měla poukázat na kulturní úpadek pohřebního rituálu a na masové využívání tématiky smrti v komerčním světě. $\mathrm{V}$ posledních letech je její symbol doslova „popularizován“. ${ }^{19}$ Znak lidské lebky se dostal do módního průmyslu, kde pozbývá svou tradiční hodnotu úcty k zemřelým. Oproti tomuto tvrzení existuje pohled na symbol smrti jako na komunikační prostředek, kterým člověk dává svému okolí najevo respekt k po-

\footnotetext{
18 Krištof Kintera: Nervous Trees. In Galerie Rudolfinum [online]. [cit. 2018-06-06]. Dostupný z www: <http://www.galerierudolfinum.cz/cs/ vystavy/archiv-vystav/kristof-kintera-nervous-trees/>

19 Výstavy přírodovědeckého muzea: Smrt. In Národní muzeum [online]. [cit. 2018-0606]. Dostupný z www: <http://www. nm.cz/ Prirodovedecke-muzeum/Vystavy-PM/Smrt. html>.
}

míjivosti života, jak píše ve své závěrečné práci studentka teologické fakulty Jihočeské univerzity v Českých Budějovicích, Andrea Rokytková. ${ }^{20} 2$ respondenti zhlédli téma týkající se eutanazie a interrupce instalované $\mathrm{v}$ exteriéru před budovou gymnázia Jakuba Škody v Přerově. Smrt a s ní spojené otázky nabývají v diskuzích dalekosáhlých argumentačních řetězců. Nekonečná polemika o životě a smrti má podobu „fenoménu kontroverze“. O smrti a jejím pojetí ve smyslu fenoménu pojednává Georg Scherer, který v otázkách svobodné vůle k rozhodnutí žít nebo zemřít opírá svá tvrzení o teze Serena Kierkegaarda a Martina Heideggera. Popisuje problém svobodné vůle k životu či smrti jako sázku do loterie, kde se mezi těmito stavy „existence" stírají rozdíly a to proto, že tíha smrti může být stejně úměrná břemenu života, $v$ němž osoba trpí. $\mathrm{V}$ případě smrti však podle něj existuje stále určitá nejistota vyplývající z nepoznaného, tzv. „po smrti“. ${ }^{21}$

Nejvíce osob, tedy 18 zúčastněných, odpovědělo, že kontroverzní pro ně byla výstava Bodies. V současné době je to nejvíce navštěvovaná, a zároveň nejvíce rozporuplná forma prezentace. Svými objekty nevšední instalace, umožňující vhled do primárně lékařské problematiky, se v naší republice uskutečnila již několikrát v Praze i v Brně. Bodies jsou oficiálně vykládány jako specificky preparovaná lidská těla, jejichž smyslem je unikátní edukační charakter. ${ }^{22}$ Vlny rozporuplných emocí zaznamenáváme z hlediska etiky. Na jedné straně budí obdiv díky svému autentickému vzhledu, na druhé straně se setkává s nega-

\footnotetext{
20 ROKYTKOVÁ, Andrea. Symboly smrti v tetováni $u$ žen na Českobudějovicku. České Budějovice: Jihočeská univerzita v Českých Budějovicích, 2015, s. 16. Bakalářská práce.

21 SCHERER, Georg. Smrt jako filosofický problém. Kostelní Vydří: Karmelitánské nakladatelství, 2005, s. 21-26.

22 Bodies. The exhibition. In Premier exhibitions [online]. [cit. 2018-06-11]. Dostupný z www: <http://www.premierexhibitions.com/ exhibitions/4/4/bodies-exhibition/learn-more $>$.
} 
tivní kritikou ve smyslu narušování lidské di̊stojnosti.

Námět přístupu k životu se objevil i v souvislosti s výstavami Dekadence now, prezentující současné dekadentní umění. Účel této tvorby spočívá v přesahování sféry společenských norem až do extrémních oblastí za jejich hranicemi. ${ }^{23}$ Jedním z představitelů moderního pojetí dekadence je Damien Hirst, jehož tvorbu pod názvem Zvírata naložená ve formaldehydu ${ }^{24}$ uvedl také jeden $\mathrm{z}$ respondentů jako kontroverzní. Reakce návštěvníků se dále dotýkaly výstavy Davida Lachapelle, který pracuje s biblickými výjevy neobvyklým způsobem jejich konfrontace se současnou společenskou situací. Např. v díle Poslední večeře dává dohromady obraz Ježíše Krista se skupinou mládeže holdující závislostem na alkoholu a drogách. ${ }^{25}$ Ustrnulá schémata pohledu na život se snaží vyvrátit také návštěvníky zmíněná autorka skleněného designu Song Mi Kim. Její galerijní instalace vycházejí z legend autorčina rodného kraje Japonska. Díla jako např. Př́běhy a legendy, upozorňují na malichernosti lidského života skrze zkušenost skutečného nebezpečí. ${ }^{26}$

Zde charakterizované výstavy, spojuje prvek identity, zasazený do významově odlišných obsahů. Získané výsledky podporují hypotetické náležitosti tohoto pojmu, viz diplomová práce s. 5-7 zabývající

23 Dekadence Now! In Galerie Rudolfinum [online]. [cit. 2018-06-11]. Dostupný z www: $<$ http://www.galerierudolfinum.cz/cs/vystavy/ archiv-vystav/decadence-now/ $>$.

24 Tamtéž

25 Tak pravil Lachapelle. In Galerie Rudolfinum [online]. [cit. 2018-06-11]. Dostupný z www: <http://www.galerierudolfinum.cz/cs/vystavy/ archiv-vystav/tak-pravil-lachapelle/>.

26 Song Mi Kim - Legenda o líném mnichovi. In Muzeum regionu Valašsko [online]. [cit. 2018-06-11]. Dostupný z www: <http://www. muzeumvalassko.cz/prohlizec/data/tiskovazprava/tiskova-zprava-tz-song-mi-kim-legendao-linem-mnichovi-2014.pdf $>$. se identitou samostatně. ${ }^{27}$ Můžeme říci, že četnost zájmu o prezentace různých podob života a smrti dokazuje přirozenou tendenci člověka někam patřit. Tvrzení o sounáležitosti použil Maslow ve svém schématu pyramidy potřeb. ${ }^{28}$

Výstavy o otázkách vnímání intimity („výstavy hodnotící a přehodnocujícíc) $)^{29}$ - 16 responsí

Náměty, převážně sexuální povahy, utvořily v množství navrácených dotazníků další skupinu, zastoupenou 16 návštěvníky. Jako první je patřičné zmínit výstavu s názvem Přirozeně, instalovanou v Moravské galerii v Brně v roce 2013, obsahující fotografie od autorů Karla Nováka a Jocka Sturgese. Tematicky se jedná o reflexi nahoty, dokumentované ve dvou různorodých dějích, odehrávajících se v politicky, sociálně i historicky odlišném kontextu. V kategorii současných problémi̊ je zahrnuta z důvodu stálé aktuálnosti a své vlastní snaze, získat místo v prostoru muzejní prezentace. Na rozdíl od většiny autorsky podnícených výstav výtvarné tvorby je tato odlišná fondem historických poznatků. Za uvedených okolností vzniká požadavek na muzeum, které by v úloze média předložilo problematiku veřejnosti. Diskuze vychází z tendencí tzv. mýtu muzejní nahoty. Tento mýtus plyne z etických zásad muzejních institucí a je spjat s individuálním postojem. Kontroverze tak nesouvisí pouze s tématem a jeho zpracováním, ale také s kompetencí dané instituce jej k vystavení přijmout. ${ }^{30}$

\footnotetext{
27 ŽÁKOVÁ, Renáta. Kontroverzní témata v muzejních výstavách. Brno: Masarykova univerzita, 2018. Magisterská diplomová práce.

28 SALVATORE, Cillela G. Fundrising for Small Museums, In good Times and Bad. Walnut Creek: AltaMira Press, 2011, s. 112-113.

29 Viz poznámka 4.

30 Přirozeně: Karel Novák - Jock Sturges. In Moravská galerie [online]. [cit. 2018-06-11]. Dostupný z www: <http://www.moravska-galerie.cz/ moravska-galerie/vystavy-a-program/aktualni-vystavy/2013/sturges_novak.aspx >.
}

Mezi dalšími navštívenými výstavami jmenujme Voayer, disponující účastí žen v roli výstavních exponátů. Rozpor vyvolávala nahota žen, vnímaná jako způsob diskriminace z hlediska genderového rozdělení. ${ }^{31}$ Jiný pohled přicházel ze strany příznivců bourání společenských tabu, kteří prožitek z výstavy popisovali jako otevření se novému poznání. Obecně respondenti odkazovali na tvorbu obou bratrů Saudků, kde je nahota klíčová. Jeden účastník šetření poukázal na zcela nemuzejní formu vystavování v souvislosti s prezentací tématu ženského cyklu $\mathrm{v}$ pražském metru.

Ze jmenovaných výstav lze vyvodit, že oblast intimity spadá převážně do uměleckého sektoru komerční sféry, a tudíž se klasické muzejní prezentaci spíše vymyká. To však můžeme říci jen v primární souvislosti s institucionální podstatou muzea. Návštěvníci totiž dle poskytnutých dat téměř nerozlišují výstavu na základě místa nebo zařízení, kde ji zhlédli. Vyjádřit se k tomuto zjištění by se hodilo spíše na konci, avšak ve spojení s problematikou, kde vzniká otázka na úlohu selekce a posuzování hodnot, byla uvážena nutnost, osvětlit poznatek dříve.

\section{Výstavy o protizákonných jednáních („výstavy tematické“) ${ }^{32}$ 4 response}

V souvislosti s protispolečenskými činy byly doručeny 4 reakce dotázaných. Odkazovaly k tematicky vysoce aktuálním výstavám. Mưžeme jmenovat 3 zahraniční. První s názvem Pout' Anderse Breivica, pořádanou v norském Oslu za účelem vzpomínky na oběti útoku masového vraha. Výstava je kontroverzní především formou zpracování. Názory odborníků šíŕí kritiku převahy

31 O výstavě: Poslední výstava skutečných nahých žen. In Voayer [online]. [cit. 2018-06-12]. Dostupný z www: <https://voayer.cz/o-vystave/ pravidla/>.

32 Viz poznámka 4 
informací o vrahovi, která podle nich odklání pozornost od skutečného záměru výstavy. Interpretace masakru měla totiž vzdávat památku obětem, nikoli vyvolávat mylná pochopení zločince, vedoucí $\mathrm{k}$ extremistickým projevům př́slušníků radikálních skupin společnosti. ${ }^{33}$

Druhá se věnuje prezentaci zaměřené na boj proti kožešinovým farmám, kterou respondent zhlédl v Nizozemí. Třetí s názvem What were you wearing?, vznikla ve státě Kansass při Eastern Mennonite University. Cílem výstavy, je vyvrátit zažitý zvyk neopodstatněného způsobu vyšetřování činů sexuálního násilí. Rekonstrukce oděvů obětí měla dle tvůrců poukázat na jejich variabilitu a s tím spojenou nízkou pravděpodobnost role ošacení, jako iniciujícího faktoru ke spáchání trestného činu. ${ }^{34}$ Mezi českými se objevuje Noční můra pandy velké. Téma necelého půl roku trvající výstavy, která již v březnu 2018 skončila, s sebou nese určitý přesah. Autorka ručně šitými medvídky, na jejichž tvorbu používá imitaci lidské kůže, reaguje na rozporuplné vystupování čínské vlády. Ukazuje, že se Čína na jedné straně angažuje v ochraně prírody, na druhé straně cíleně zabíjí vězně za účelem obchodu s orgány. Postava hračky medvídka pandy, viz obr. $1,{ }^{35}$ spojuje pocit dětské útěchy v konfrontaci s odvrácenou stranou jednání s lidmi. Problematika je ztělesněna v národním symbolu Č́ny, na jehož

33 Breivikův masakr nově připomíná výstava. Kritici mluví o modle extremistů. In iDNES.cz [online]. [cit. 2018-06-12]. Dostupný z www: $<$ https://zpravy.idnes.cz/v-norsku-se-oteviravystava-o-breivikovi-rodice-jeho-obeti-staletrpi-1kz-/zahranicni.aspx?c=A150722_154301 zahranicni_kha>

34 Local partnership brings 'What Were You Wearing?' survivor art installation to EMU, three other locations. In Eastern Mennonite University [online]. [cit. 2018-06-12]. Dostupný z www: $<$ https://emu.edu/now/news/2018/03/localpartnership-brings-what-were-you-wearing survivor-art-installation-to-emu-three-otherlocations/ $>$.

35 Obrazová př́loha k výstavě Noční mưra pandy velké [online]. [cit. 2018-11-05]. Dostupný z www: $<$ http://www.barborabalkova.cz/images/big/ panda23.jpg $>$.

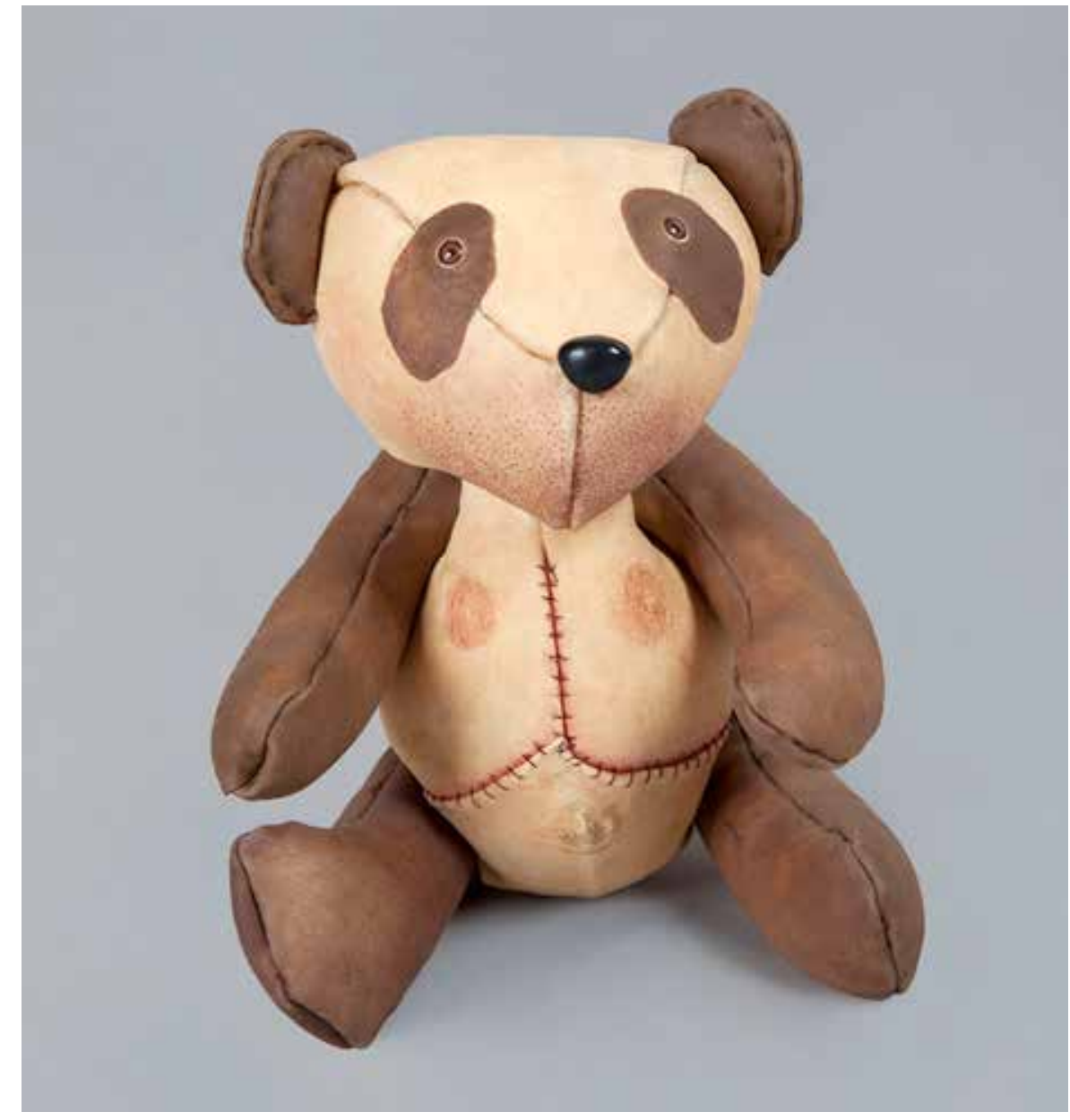

Obr.1: Výstava Noční mưra pandy velké (GASK, Kutná Hora)

výrobu byl použit materiál, připomínající oběti lidské zvůle. ${ }^{36}$

V odpovědích návštěvníků se vyskytly celkem 3 př́klady z kategorie protiprávního jednání, které byly prezentovány $\mathrm{v}$ zahraničí.

Výsledek svědčí o méně časté reflexi vysoce citlivých témat v České republice v porovnání s vyspělejšími zeměmi. Všimněme si, že navštívené výstavy demonstrují základní formy násilí. Mưžeme v nich rozlišovat násilí na člověku jako jednotlivci, na masách společnosti nebo na zvíratech.

36 Komunismus s pandí tváríi. In Barbora Bálková [online]. [cit. 2018-06-13]. Dostupný z www: <http://www.barborabalkova.cz/pandy.html>.

\subsubsection{Výstavy zaměřené na člo-} věka a identitu („výstavy hodnotící a přehodnocujíci“") ${ }^{37}-4$ response

Pro problematiku kontroverze $\mathrm{v}$ interpretaci identity byla vytvořena samostatná kategorie zařazení.

Respondenty zde zmíněná témata se totiž váží převážně na podstatu existence. Ukotvení v čase hraje až druhořadou roli. $\mathrm{K}$ tématu identity odkazují 4 response, z toho 2 příklady připadají výstavě Šumění andělských kř́del konané v Muzeu umění v Olomouci, která se vyrovnává s rozporem využitím vizuální variability vystavovaných objektů. Hlavní postava anděla je prezentována $\mathrm{v}$ různých rolích $\mathrm{s}$ uplatněním mnoha uměleckých stylů, směrů

\footnotetext{
37 Viz poznámka 4.
} 
a technik. Nyní však věnujme pozornost rozporuplnému projektu 3 kila osudu. Námět reflektuje právo člověka na zachování identity po smrti. Autorem prezentujícím toto téma po většinu doby roku 2013 v Egon Schiele Art Centru v Českém Krumlově je Roman Týc. Předvedl dílo, založené na malování portrétů z popela, jímž se snažil vzbudit cílenou diskuzi. Účelu vyvolání kontroverze předcházela myšlenka nesouhlasu s nakládáním s lidskými ostatky v zařízeních krematorií. Kromě portrétů $\mathrm{z}$ popela, kvůli jehož spekulativní povaze, odkud materiál pochází, byl umělec obviněn, jsou $\mathrm{k}$ vidění $\mathrm{i}$ další formy umění. Identitu zemřelého člověka např. zapisuje do symbolu QR kódu, ${ }^{38}$ viz obr. $2 .{ }^{39}$ Kód maluje taktéž směsí popela. ${ }^{40} \mathrm{~V}$ případě této výstavy je kontroverze snadno předvídatelná. Interpretace palčivého tématu provázená dobrým úmyslem na druhé straně hraničí s porušováním zákona. Byt’ autor využívá jen menšiny ostatků popela, který skončí v krematoriích jako odpadní materiál, stává se participantem činu. V tomto momentu stojí proti sobě etika a logika, střet zájmů dvou stran, jejichž argumenty vycházejí z odlišných kontextů, a proto je těžké, označit jeden nebo druhý za relevantnější.

Posledním příkladem, zaznamenaným mezi responsemi o kontroverzi v oblasti identity, je výstava čínského autora Aj Wej-weje, nazvaná Zákon cesty. Interpretace problematiky uprchlické krize je zde sou-

38 QR kód je informační datový kód, vytvořený dle platné formy ISO 18004. Jeho hlavní složky tvoří geometrická a informační vrstva. Načtením kódu příslušnou aplikací lze získat neviditelný informační obsah. Funkčnost kódu spočívá v definici skryté v písmenech zkratky QR, kdy Q znamená „quick“ a R „response," tedy, jedná se o rychlé poskytnutí informací. Současně je již hojně využíváno na spoustě veřejných míst po celém světě.

39 Obrazová př́loha k výstavě 3 kila osudu [online]. [cit. 2018-11-05]. Dostupný z www: <http:// www.schieleartcentrum.cz/cs/roman-tyc/92/>.

40 Roman Týc: 3 kila osudu. In Egon Schiele Art Centrum Český Krumlov [online]. [cit. 2018-06-21]. Dostupný z www: <http://www. schieleartcentrum.cz/cs/roman-tyc/92/>.

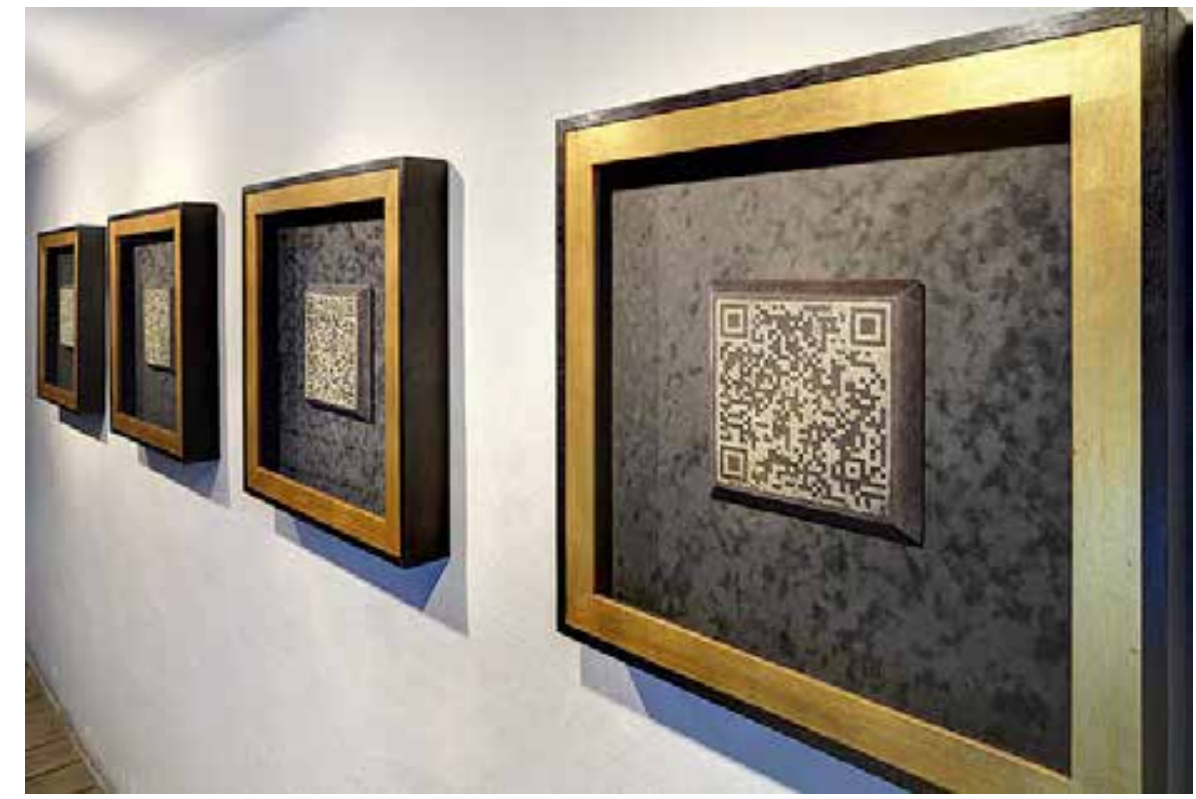

Obr. 2: Výstava 3 kila osudu (Egon Schiele Art Centrum, Český Krumlov)

středěna na jeden monumentální vystavovaný předmět, rozměrný nafukovací člun s 258 modely postav uprchlíků. Snaha šokovat byla vyvinuta prvoplánově. Užitý materiál má svou vratkou fyzickou povahou metaforicky přibližovat nejistotu, plynoucí ze samotné situace dění prezentovaného tématu. ${ }^{41}$

Závěrem $\mathrm{k}$ této kategorii výstav můžeme říci, že se v jejich zastoupení promítají klíčové problémy současnosti, kde vystupuje člověk jako jednotlivec do popředí. Zmíněné kontroverzní výstavy charakterizují přístup člověka $\mathrm{k}$ víře, náboženství a vnitřním i vnějším podmínkám své existence ve vztahu k vlastní osobě.

3.3.4 Výstavy o současné autorské tvorbě („výstavy tematické, výstavy hodnotící a prehodnocující, výstavy skupinovéc) $)^{42}-9$ responsí

Příklady výstav se týkaly především alternativních přístupů v umě-

\footnotetext{
41 Aj Wej-wej. Zákon cesty. In Národní galerie $v$ Praze [online]. [cit. 2018-06-21]. Dostupný z www: <https://www.ngprague.cz/expositiondetail/aj-wej-wej/>

42 Viz poznámka 4.
}

ní, jako je performance. ${ }^{43} \mathrm{Z}$ uvedených podnětů v dotaznících lze jmenovat např. výstavu záchodových mís, prezentovanou v Centre Pompidou v Paříži. Jedná se o projekt hnutí Fluxus, jehož účelem je sabotovat umění jako takové. Původem neuměleckými objekty toalet se snaží poukázat na skutečnost, že uměním může být cokoli. Vzhledem k opravdovému přijetí a vystavení objektů, postrádajících uměleckou zručnost, vyvolal tento počin kontroverzi mezinárodního měřítka. Přispělo k ní také rozšíření výstavy do světově známých institucí, jako je Tate Modern v Londýně nebo National Gallery v Kanadě. ${ }^{44}$

\subsubsection{Ostatní příklady považo- vané za kontroverzní výstavy - 7 responsí}

Specifickou kategorii utvořily vlastní názory respondentů, které nebylo možno blíže vyhledat nebot' se v žádném z prríkladi̊, nejednalo

43 Viz výklad stejného pojmu výše v kapitole 4.2.2.

44 Toilets, Art and Fluxus. In Toilets as Modern and Contemporary art: The Fluxus Movement [online]. [cit. 2018-06-23]. Dostupný z www: <https:// toilet-guru.com/fluxus.php $>$. 
primárně o muzejní prezentaci. Jeden $\mathrm{z}$ dotázaných uvedl např. svůj vlastní život, jenž mu připomíná kontroverzní výstavu. Podobně zaznělo vyjádření $\mathrm{k}$ divadelnímu vystoupení nebo tzv. „podomácku“ realizovaná performance $s$ hračkami panenek pověšenými po celé délce podél stř̌ešního krovu vlastního domu majitele, coby autora. $\mathrm{V}$ případě divadla není $\mathrm{z}$ odpovědi respondenta znát, zda použil takovou metaforu náhodně, či již někdy slyšel o metodě interpretace vycházející z modelu divadelní scény. Metoda se efektivně uplatňuje v edukačních programech s cílovou skupinou osob s ADHD. ${ }^{45}$ Funguje jako nástroj.

\section{Závěrečné vyhodnocení}

Stejně jako v diplomové práci, i v tomto př́ispěvku byl znovu vysvětlen pojem kontroverze, jeho vznik v interpersonálním a intrapersonálním důsledku či z důvodu tzv. aktualizace dějin. Pozornost byla věnována také pěti hlavním oblastem kontroverzního dění a totiž identitě, autenticitě, estetice, etice a právu. Můžeme říci, že pojem kontroverze tímto dostal pevné místo v kontextu metodologických přístupů. Byl vyňat $\mathrm{z}$ abstraktního chápání, jelikož se jej podařilo rozklíčovat. Nově výchozí pojmová základna tak zpřesnila jeho identifikaci a podnítila využitelnost v praktickém výzkumu. Realizace dotazníkového šetření, které se $\mathrm{v}$ tomto článku soustředí na témata navštívených výstav, přinesla následující výsledky.

Nové poznatky přispěly $\mathrm{k}$ utvrzení hypotetických předpokladů v odborné literatuře, hovořících o reflexi současnosti se stejnou vahou,

45 NIKONANOU, Niki a Foteini VENIERI. Interpreting social issues: Museum theatre's potential for critical engagement. Museum and Society [online]. University of Leicester: Museum Studies, březen 2017, roč. 15, č. 1, s. 17 [cit. 2018-0623]. Dostupný z www: <https://www2.le.ac.uk/ departments/museumstudies/museumsociety/

documents/volumes/nikonanou-venieri>. jako ji vnímají návštěvníci muzeí. Obdobně jsou v jejich odpovědích čitelné hlavní rysy námětů výstav, korespondujích se stěžejními problémy společnosti, zejména s životním stylem a politickými událostmi. Na současnost se soustředilo 68 respondentů, což tvoří $64 \%$ $\mathrm{z}$ celku 106. Pro více než polovinu osob, které navštívily kontroverzní výstavu, je aktuálnost tématu prioritou. Tento fakt znovu potvrdily také výpovědi u 11 . otázky dotazníku, která přímo zjištovala, o jaká témata mají návštěvníci zájem. Kategorie aktuálních, reagujících na okolní dění byla zastoupena 125 hlasy. Lidé tedy všeobecně upřednostňují poznatky využitelné k pozvednutí kvality vlastního života nebo svých blízkých. Proto ve výstavách vyhledávají znaky shodné $s$ prvky obsaženými $v$ jejich osobních či meziosobních problémech. Ty se snaží nadále identifikovat, porovnávat a hodnotit. Právě ono hodnocení se stává častým podnětem ke kontroverzi.

\section{Dodatek}

At̉ už závěry této studie hovoří jakkoliv utilitárně, je nutné zohlednit, že muzea jsou ve své původní podstatě zdroji poznatků a vědění, a proto by jejich prrístup měl zachovat určitou interdisciplinaritu, nikoliv podléhat spotřebitelským ukazatelům $\mathrm{v}$ roli muzejního návštěvníka. To ovšem nijak nevylučuje vstřícný př́istup a ohled na individuální potřeby různých návštěvnických cílových skupin. Efektivita práce s výstavami a kontroverzí spočívá spíše v konkrétních prríkladech, kde je možné aplikovat např. metody kritického myšlení a projektový plán, zejména při spolupráci v týmu. Negativním vlivům lze preventivně předcházet včasnou informovaností a zapojením rizikových skupin společnosti do souvisejících aktivit ještě před zahájením výstavy.

\section{LITERATURA:}

MASLOWSKI, Nicolas a Jiří ŠUBRT. Kolektivní pamět: $k$ teoretickým otázkám. Praha: Karolinum, 2015. ISBN

978-80-246-2689-5.

ROKYTKOVÁ, Andrea. Symboly smrti $v$ tetování u žen na Českobudějovicku. České Budějovice: Jihočeská univerzita v Českých Budějovicích, 2015. Bakalářská práce.

SALVATORE, Cillela G. Fundrising for Small Museums, In good Times and Bad. Walnut Creek: AltaMira Press, 2011. ISBN 0-7591-1969-4.

SCHERER, Georg. Smrt jako filosofický problém. Kostelní Vydří: Karmelitánské nakladatelství, 2005. ISBN 80-7192-914-X.

TABORSKY, Edwina. The discursive Objects. In PEARCE, Susan. Objects of knowledge. London: The Atlone Press, 1990, s. 5077. ISBN 0-485-90001-7.

Ukázka typologie a klasifikace výstav podle D. Šindeláře, Umění ve vědomí společnosti, s. 66. In ŠTĚPÁNEK, Pavel. Obrysy muzeologie. Olomouc: Univerzita Palackého v Olomouci, 2002, s. 71. ISBN 80-244-0542-3.

ŽÁKOVÁ, Renáta. Kontroverzní témata ve výstavách, cílové skupiny, efektivita a možnosti rizik. Múzeum, 2017, roč. 63, č. 3, s. 10-11. ISSN 0027-5263

ŽÁKOVÁ, Renáta. Kontroverzní témata v muzejních výstavách. Brno: Masarykova univerzita, 2018. Magisterská diplomová práce.

ŽÁKOVÁ, Renáta. Výstavní menu aneb jak podávat kontroverzi. In TIŠLIAR, Pavol (ed.). Studia Museologica Slovaca, 2018, vol. 2. Bratislava: Muzeológia a kultúrne dedičstvo, 2018, s. 51-55. ISBN

978-80-89881-12-3.

Elektronické zdroje:

NIKONANOU, Niki a Foteini VENIERI. Interpreting social issues: Museum theatre's potential for critical engagement. Museum and Society [online]. University of Leicester: Museum Studies, březen 2017, roč. 15, č. 1, s. 17 [cit. 2018-06-23]. Dostupný z www: <https://www2. le.ac.uk/departments/museumstudies/ museumsociety/documents/volumes/ nikonanou-venieri $>$. 


\section{Zdroje dat $\mathbf{k}$ výzkumnému šetření:}

Aj Wej-wej. Zákon cesty. In Národní galerie $v$ Praze [online]. [cit. 2018-06-21]. Dostupný z www: <https://www.ngprague. cz/exposition-detail/aj-wej-wej/>.

Andy Warhol - 15 minut slávy. In Opavská kulturní organizace [online]. [cit. 2018-06-09]. Dostupný z www: <http:// dumumeniopava.cz/?s=Andy+Warhol $>$.

Bodies. The exhibition. In Premier exhibitions [online]. [cit. 2018-06-11]. Dostupný z www: <http://www. premierexhibitions.com/exhibitions/4/4/ bodies-exhibition/learn-more $>$.

Breivikův masakr nově připomíná výstava. Kritici mluví o modle extremistů. In iDNES.cz [online]. [cit. 2018-06-12]. Dostupný z www: <https:// zpravy.idnes.cz/v-norsku-se-oteviravystava-o-breivikovi-rodice-jehoobeti-stale-trpi-1kz-/zahranicni. aspx?c=A150722_154301_zahranicni_ kha $>$.

ČS koncept 70. let. In Fait Gallery [online]. [cit. 2018-06-09]. Dostupný z www: $<$ https://www.faitgallery.com/soucasnea-planovane/events/244.html>.

Dekadence Now! In Galerie Rudolfinum [online]. [cit. 2018-06-11]. Dostupný z www: <http://www. galerierudolfinum.cz/cs/vystavy/archivvystav/decadence-now/>.

Kmeny 90. In Moravská galerie [online]. [cit. 2018-06-06]. Dostupný z www: <http:// www.moravska-galerie.cz/moravskagalerie/vystavy-a-program/aktualnivystavy/2017/kmeny-90.aspx >.

Komunismus s pandí tváří. In Barbora Bálková [online]. [cit. 2018-06-13]. Dostupný z www: <http://www. barborabalkova.cz/pandy.html>.

Krištof Kintera: Nervous Trees. In Galerie Rudolfinum [online]. [cit. 2018-06-06]. Dostupný z www: <http://www.galerie rudolfinum.cz/cs/vystavy/archiv-vystav/ kristof-kintera-nervous-trees/>.

Local partnership brings 'What Were You Wearing?' survivor art installation to
EMU, three other locations. In Eastern Mennonite University [online]. [cit. 2018-06-12]. Dostupný z www: <https:// emu.edu/now/news/2018/03/localpartnership-brings-what-were-youwearing-survivor-art-installation-toemu-three-other-locations/>.

Magdalena Abakanowicz. Život a dílo. In Muzeum umění Olomouc [online]. [cit. 2018-06-06]. Dostupný z www: <http:// www.muo.cz/vystavy-2011/magdalenaabakanowicz-zivot-a-dilo--340/>.

O výstavě: Poslední výstava skutečných nahých žen. In Voayer [online]. [cit. 2018-06-12]. Dostupný z www: <https:// voayer.cz/o-vystave/pravidla/>.

Ozvěny Secese. In Galerie města Olomouce [online]. [cit. 2018-06-09]. Dostupný z www: <http://www.galerie-mestaolomouce.cz/aktualita/cz/66>.

Paneland. Největší československý experiment. In Moravská galerie [online]. [cit. 2018-06-10]. Dostupný z www: <http://www.moravska-galerie.cz/ moravska-galerie/vystavy-a-program/ aktualni-vystavy/2017/paneland.aspx >.

Přirozeně: Karel Novák - Jock Sturges. In Moravská galerie [online]. [cit. 2018-06-11]. Dostupný z www: <http:// www.moravska-galerie.cz/moravskagalerie/vystavy-a-program/aktualnivystavy/2013/sturges_novak.aspx >.

Roman Týc: 3 kila osudu. In Egon Schiele Art Centrum Český Krumlov [online]. [cit. 2018-06-21]. Dostupný z www: <http:// www.schieleartcentrum.cz/cs/romantyc/92/>.

Song Mi Kim - Legenda o líném mnichovi. In Muzeum regionu Valašsko [online]. [cit. 2018-06-11]. Dostupný z www: <http://www.muzeumvalassko.cz/ prohlizec/data/tiskova-zprava/tiskovazprava-tz-song-mi-kim-legenda-o-linemmnichovi-2014.pdf $>$.

Tak pravil Lachapelle. In Galerie Rudolfinum [online]. [cit. 2018-06-11]. Dostupný z www: <http://www. galerierudolfinum.cz/cs/vystavy/archivvystav/tak-pravil-lachapelle/>.
Toilets, Art and Fluxus. In Toilets as Modern and Contemporary art: The Fluxus Movement [online]. [cit. 2018-06-23]. Dostupný z www: <https://toilet-guru.com/ fluxus.php>.

V muzeu Kampa je k vidění kontroverzní sousoší umělecké skupiny Pode Bal. In Lidovky.cz [online]. [cit. 2018-06-

-12]. Dostupný z www: <https://www. lidovky.cz/v-museu-kampa-je-

k-videni-kontroverzni-sousosi-umeleckeskupiny-pode-bal-1qm-/kultura. aspx?c=A150720_110338_ln_kultura_ hep $>$.

Výstava plná rozporu - dotazníkové šetření vztahu návštěvníků muzeí a galerií ke kontroverzním výstavám [online]. [cit. 2018-11-15]. Dostupný z www: $<$ https://www.survio.com/survey/d/ W4X9N0T9U1X1B5E8N>.

Výstavy př́rodovědeckého muzea: Smrt. In Národní muzeum [online]. [cit. 201806-06]. Dostupný z www: <http:// www. nm.cz/Prirodovedecke-muzeum/ Vystavy-PM/Smrt.html>.

\section{RENÁTA ŽÁKOVÁ}

\section{7@mail.muni.cz}

Absolventka oboru Muzeologie (2018) v magisterském studijním programu Historické vědy na Filozofické fakultě Masarykovy univerzity v Brně. Zaměřuje se na problematiku muzejního výstavnictví a metod kritického myšlení.

Graduate in the field of Museology (2018) within the master's study programme Historical Sciences at the Faculty of Arts, Masaryk University in Brno. She is focused on the problem of museum exhibitions and critical thinking methods. 